\title{
Thermal Decomposition Kinetics of Ni(II) Chelates of Substituted Chalcones
}

\author{
K.G.MALLIKARJUN \\ Department of chemistry, Jawahar Navodaya Vidyalaya \\ Peddapuram - 533 437, East Godavari, (A.P.) India.
}

Received 22 February 2004; Accepted 10 March 2004

\begin{abstract}
The thermal decomposition of $\mathrm{Ni}(\mathrm{II})$ complexes of 3-(phenyl)-1-(2'hydroxy-naphthyl)-2-propen-1-one (PHPO), 3-(4-chlorophenyl)-1-(2'-hydroxynaphthyl)-2-propen-1-one(CPHPO), 3-(4-methoxyphenyl)-1-(2'-hydroxynapthyl)-2propen-1-one (MPHPO), 3-(3,4-dimethoxyphenyl)-1-(2'-hydroxynaphthyl)-2propen-1-one(DMPHPO) was studied by thermogravimetry. Mathematical analysis of the data has allowed us to determine various parameters using Freeman-Carroll equation, the integral method using the coats-Redfern equation and the approximation method using the Horowitz-Metzger equation. The trend of the kinetic parameters was found to be different from that of the thermal stability order. The low values of $\mathrm{Z}$ suggest the slow nature of the reaction.
\end{abstract}

Keywords: Thermogravimetry, Chalcones, Nickel Compounds, Frequency factor,

\section{Introduction}

Very few systems have been reported ${ }^{1}$ showing the relationship between thermal stability of metal chelates and structure of the chelating agents. Wendlandt and co-workers ${ }^{2-5}$ and Hill and co-workers ${ }^{6,7}$ studied the thermal properties of metal chelates with different types of complexing ligands. Structural studies on several metal chelates of $\beta$-diketones and 2-hydroxycarbonyl compounds have been reviewed by Holm and $\mathrm{O}^{\text {' Connor. }}{ }^{8}$ The metal chelates of divalent transition metals with some $o$-hydroxychalcones standout as a distinct class of $o$-hydroxycarbonyl compounds with low spin square-planar configuration, which do not easily form adduct. Extensive conjugation was found to be responsible for the strong field nature of the ligand. ${ }^{9}$ Chalcones usually exhibit germicidal ${ }^{10}$ bactericidal ${ }^{11}$ fungicidal ${ }^{12}$ and carcinogenic activities. ${ }^{13}$

In continuation of our earlier work ${ }^{14-19}$ on thermal decomposition kinetics of metal chelates, the present investigation deals the thermal stability of the Nickel chelates of 3 - (phenyl) -1 - ( 2'hydroxynaphthyl ) - 2 - propen -1 -one (PHPO) , 3 - ( 4 - chlorophenyl ) - 1- (2'- hydroxynaphthyl ) 2 - propen -1 -one (CPHPO), 3 - ( 4 - methoxyphenyl ) - 1 - (2'- hydroxynapthyl ) - 2-propen -1- one (MPHPO), 3-(3,4-dimethoxyphenyl)-1-(2'-hydroxynaphthyl)-2-propen-1-one (DMPHPO) and evaluation of kinetic parameters employing the differential Freeman-Carroll equation ${ }^{20}$ the integral method using the Coats-Redfern equation ${ }^{21}$ and the approximation method using the HorowitzMetzger equation. ${ }^{22}$ 


\section{Experimental}

The chalcones were prepared by the condensation of 2-hydroxy-1-acetonaphthone with benzaldehyde, chlorobenzaldehyde, methoxybenzaldehyde and dimethoxybenzaldehyde employing the ClaisenSchmidt condensation reported earlier. ${ }^{23}$ The copper complexes of chalcones were prepared by refluxing a toluene solution of nickel acetate and the ligand in 1:2 molar ratios, in the presence of dilute ammonia ( $\mathrm{pH} 8.5-9.0$ ) for $1 \mathrm{~h}$. The precipitates were filtered, washed with toluene and dried in a vacuum desiccator over fused calcium chloride. The purity of the sample was checked by elemental analysis. The thermograms were recorded using a Perkin-Elmer TGS-2 thermo balance in ambient air and at a heating rate of $6 \mathrm{~K} \mathrm{~min}^{-1}$. Kinetic data were evaluated from TG traces using the equations noted in Table-1.

Table 1. Kinetic data

\begin{tabular}{|c|c|c|c|c|}
\hline Chelate & Parameters & $\begin{array}{l}\text { From Freeman- } \\
\text { Carroll equation }\end{array}$ & $\begin{array}{l}\text { From Coats- } \\
\text { Redfern equation }\end{array}$ & $\begin{array}{l}\text { From Horowitz- } \\
\text { Metzger equation }\end{array}$ \\
\hline $\mathrm{Ni}(\mathrm{PHPO})_{2}$ & $\begin{array}{l}\mathrm{E}^{*}\left(\mathrm{kcal} \mathrm{mol}^{-1}\right) \\
\mathrm{Z}\left(\mathrm{s}^{-1}\right) \\
\Delta \mathrm{S}^{*}(\text { e.u. }) \\
\mathrm{G}^{*}\left(\mathrm{kcal} \mathrm{mol}^{-1}\right) \\
\mathrm{K}_{\mathrm{r}}\left(\mathrm{Su}^{-1}\right)\end{array}$ & $\begin{array}{l}2.84 \\
5.63 \times 10^{-2} \\
-29.49 \\
16.69 \\
5.61 \times 10^{-2}\end{array}$ & $\begin{array}{l}2.27 \\
2.49 \times 10^{-3} \\
-33.08 \\
18.41 \\
2.43 \times 10^{-3}\end{array}$ & $\begin{array}{c}8.95 \\
6.04 \\
-25.19 \\
21.24 \\
6.01\end{array}$ \\
\hline $\mathrm{Ni}(\mathrm{CPHPO})_{2}$ & $\begin{array}{l}\mathrm{E}^{*}\left(\mathrm{kcal} \mathrm{mol}^{-1}\right) \\
\mathrm{Z}\left(\mathrm{s}^{-1}\right) \\
\Delta \mathrm{S}^{*}(\mathrm{e} . \mathrm{u} .) \\
\mathrm{G}^{*}\left(\mathrm{kcal} \mathrm{mol}^{-1}\right) \\
\mathrm{K}_{\mathrm{r}}\left(\mathrm{Su}^{-1}\right)\end{array}$ & $\begin{array}{l}4.79 \\
2.54 \times 10^{-1} \\
-28.25 \\
18.33 \\
2.51 \times 10^{-1}\end{array}$ & $\begin{array}{l}3.19 \\
8.07 \times 10^{-3} \\
-32.16 \\
18.66 \\
7.93 \times 10^{-3}\end{array}$ & $\begin{array}{r}12.24 \\
96.18 \\
-23.06 \\
17.10 \\
95.49\end{array}$ \\
\hline $\mathrm{Ni}(\mathrm{MPHPO})_{2}$ & $\begin{array}{l}\mathrm{E}^{*}\left(\mathrm{kcal} \mathrm{mol}^{-1}\right) \\
\mathrm{Z}\left(\mathrm{s}^{-1}\right) \\
\Delta \mathrm{S}^{*}(\text { e.u. }) \\
\mathrm{G}^{*}\left(\mathrm{kcal} \mathrm{mol}^{-1}\right) \\
\mathrm{K}_{\mathrm{r}}\left(\mathrm{Su}^{-1}\right)\end{array}$ & $\begin{array}{c}7.14 \\
1.01 \\
-26.14 \\
20.29 \\
0.99\end{array}$ & $\begin{array}{l}11.18 \\
2.98 \times 10 \\
-23.75 \\
23.13 \\
28.70\end{array}$ & $\begin{array}{l}13.95 \\
3.76 \times 10^{2} \\
-21.92 \\
24.98 \\
3.69 \times 10^{2}\end{array}$ \\
\hline $\mathrm{Ni}(\mathrm{DMPHPO})_{2}$ & $\begin{array}{l}\mathrm{E}^{*}\left(\mathrm{kcal} \mathrm{mol}^{-1}\right) \\
\mathrm{Z}\left(\mathrm{s}^{-1}\right) \\
\Delta \mathrm{S}^{*}(\text { e.u. }) \\
\mathrm{G}^{*}\left(\mathrm{kcal} \mathrm{mol}^{-1}\right) \\
\mathrm{K}_{\mathrm{r}}\left(\mathrm{su}^{-1}\right)\end{array}$ & $\begin{array}{l}8.69 \\
3.16 \\
-25.37 \\
21.89 \\
3.13\end{array}$ & $\begin{array}{l}14.06 \\
4.12 \times 10^{2} \\
-21.22 \\
25.06 \\
4.09 \times 10^{2}\end{array}$ & $\begin{array}{l}16.04 \\
44.57 \times 10^{2} \\
-18.92 \\
25.82 \\
44.35 \times 10^{2}\end{array}$ \\
\hline
\end{tabular}

\section{Results and Discussion}

All the complexes are coloured powders which are insoluble in water. The elemental analysis of the chelates showed nickel to ligand ratios of 1:2. The complexes were found to be stable in air and nonhygroscopic. The final pyrolysis product of all the complexes corresponds to NiO. The relative thermal stability of the chelates is (Table 2 ) $\mathrm{Ni}(\mathrm{CPHPO})_{2}<\mathrm{Ni}(\mathrm{PHPO})_{2}<\mathrm{Ni}(\mathrm{MPHPO})_{2}<\mathrm{Cu}(\mathrm{DMPHPO})_{2}$. Mathematical analysis of the TG curves was carried out using the differential Freeman-Carroll equation, the integrate method using the Coats-Redfern equation and the approximation method using the Horowitz-Metzger equation. 
Table 2. Thermal decomposition data

\begin{tabular}{|c|c|c|c|c|c|}
\hline \multirow{3}{*}{ Chelate } & \multirow{3}{*}{$\begin{array}{c}\text { Decomposition } \\
\text { Temp. } \\
\left({ }^{0} \mathrm{C}\right)\end{array}$} & \multicolumn{3}{|c|}{ Residue (Percentage) } & \multirow{3}{*}{$\begin{array}{l}\text { Order of reaction } \\
\text { Freeman-Carroll } \\
\text { Method }\end{array}$} \\
\hline & & Theoretica & & Experiment & \\
\hline & & Metal & Oxide & & \\
\hline $\mathrm{Ni}(\mathrm{PHPO})_{2}$ & 215 & 10.04 & 12.78 & 13.21 & 1.09 \\
\hline $\mathrm{Ni}(\mathrm{CPHPO})_{2}$ & 208 & 9.50 & 12.08 & 12.56 & 1.14 \\
\hline $\mathrm{Ni}(\mathrm{MPHPO})_{2}$ & 230 & 9.11 & 11.59 & 11.35 & 1.18 \\
\hline $\mathrm{Ni}(\mathrm{DMPHPO})_{2}$ & 244 & 8.31 & 10.57 & 12.04 & 1.11 \\
\hline
\end{tabular}

FREEMANN-CARROLL EQUATION

Freeman-Carroll equation which may be written in the form.

$$
\frac{\Delta \log (d W / d t)}{\Delta \log W_{r}}=\frac{-\left(E^{*} / 2.303 R\right) \Delta\left(T^{-1}\right)}{\Delta \log W_{r}}+n
$$

Where $\mathrm{W}_{\mathrm{r}}=\mathrm{W}_{\alpha}-\mathrm{W}, \mathrm{W}_{\alpha}$ is the mass loss at the completion of reaction, $\mathrm{W}$ is the mass loss up to time $\mathrm{t}, \mathrm{T}$ is the absolute temperature at time $\mathrm{t}, \mathrm{n}$ is the order of reaction. $\mathrm{R}$ is the gas constant in calories and $\mathrm{E}^{*}$ is the energy of activation in $\mathrm{K} \mathrm{cal} \mathrm{mol}^{-1} . \mathrm{W}_{\mathrm{r}}$ and $\mathrm{T}$ can be directly obtained from the TG traces. The temperature slopes $\mathrm{dW} / \mathrm{dT}$ were converted into time slopes $\mathrm{dW} / \mathrm{dt}$, using the relation ${ }^{23}$

$$
\frac{d W}{d t}=\frac{d W}{d T} \cdot \frac{d T}{d t}=\left(\frac{d W}{d t}\right) \phi
$$

where $\phi$ is the heating rate. The usual first-order rate law expression

$$
\frac{d W}{d t}=k(a-x)
$$

can be written in the following form using the terms $\mathrm{W}$ and $\mathrm{W}_{\mathrm{r}}$

$$
\frac{d W}{d t}=k W_{r}
$$

Combining this with the Arrhenius equation

We obtain

$$
\mathrm{K}=\mathrm{Z} \exp \left(-\mathrm{E}^{*} / \mathrm{RT}\right)
$$

$$
\log \left(\frac{d W / d t}{W_{r}}\right)=-\frac{E^{*}}{2.303 R T}+\log Z
$$

Plot of $\log \left[(\mathrm{dw} / \mathrm{dt}) / \mathrm{W}_{\mathrm{r}}\right]$ against $\mathrm{T}^{-1}$ were drawn. They gave straight lines in all cases with slopes $-E^{*} / 2.303 R$ from which $E^{*}$ values were obtained. $Z$ was calculated from the above equation and the entropy of activation $\Delta \mathrm{S}^{*}$ was obtained from the relation ${ }^{24}$

$$
\Delta \mathrm{S}^{*}=2.3 .3 \mathrm{R} \log \left(\mathrm{Zh} / \mathrm{kT}_{\mathrm{s}}\right)
$$

Where $\mathrm{k}$ is the Boltzmann constant, $\mathrm{h}$ is the Planck constant and $\mathrm{T}_{\mathrm{s}}$ is the peak temperature from DTG. The free energy of activation $\mathrm{G}^{*}$ was calculated using the following equation ${ }^{25}$

$$
\begin{aligned}
& \mathrm{G}^{*}=\mathrm{E}^{*}-\mathrm{T}_{\mathrm{s}} \Delta \mathrm{S}^{*} \\
& \mathrm{~K}_{\mathrm{r}}=\mathrm{Z} \exp \left(-\mathrm{E}^{*} / \mathrm{RT}_{\mathrm{s}}\right)
\end{aligned}
$$




\section{COATS-REDFERN EQUATION}

$$
\log \left[\ln \frac{\frac{W_{\infty}}{W^{2}}}{T^{2}}\right]=\log \left[\frac{Z R}{\phi E^{*}}\left(1-\frac{2 R T}{E^{*}}\right)\right]-\frac{E^{*}}{2.303 R T}
$$

Where $\mathrm{W}_{\infty}=$ mass loss at the completion of the reaction,

$\mathrm{W}=$ mass loss at time,

$\mathrm{Z}=$ frequency factor,

$\Phi^{*}=$ linear rate of heating

$\mathrm{E}^{*}=$ activation energy of the reaction.

Assuming the decomposition of $\mathrm{Ni}(\mathrm{II})$-chalcone chelates to follow first order kinetics $(\mathrm{n}=1)$ a plot of $\log \left\{\ln \left[(\mathrm{W} \infty /(\mathrm{W} \infty-\mathrm{W})) / \mathrm{T}^{2}\right]\right\}$ against $1 / \mathrm{T}$ was drawn which gave straight lines in all cases with a slope of $-\mathrm{E}^{*} / 2.303 \mathrm{R}$ from which the activation energy was calculated.

\section{HOROWITZ-METZGER EQUATION}

$$
\log \log \frac{W_{\infty}}{W_{r}}=\frac{E^{*} \phi}{2.303 R T_{s}^{2}}-\log 2.303
$$

Where, $W_{\infty}=$ mass loss at the completion of the reaction,

$\mathrm{W}_{\mathrm{r}}=\mathrm{W} \infty-\mathrm{W}$,

$\mathrm{W}=$ mass loss at time $\mathrm{t}$,

$\mathrm{T}_{\mathrm{s}}=$ peak temperature,

$\mathrm{R}=$ gas constant.

A plot of $\log \log \mathrm{W} \infty / \mathrm{W}_{\mathrm{r}}$ against $\theta$ was drawn which gave straight lines in all the cases with the slope $\mathrm{E}^{*} / 2.303 \mathrm{RT} \mathrm{T}_{\mathrm{s}}^{2}$ from which $\mathrm{E}^{*}$ values were obtained.

\section{Decomposition kinetics}

The analysis of data using the Freeman-Carroll equation gives the order of the decomposition reaction near unity for these complexes. The values of activation energy $\mathrm{E}^{*}$ obtained by all three methods for the nickel chelates are given ( Table 1 ). The negative values of $\Delta S^{*}$ indicates that the activated complex has a more ordered structure than the reactants ${ }^{24}$ and further the low values of $\mathrm{Z}$ indicate the slow nature of the reaction ${ }^{27}$.

The values of $\mathrm{E}^{*}$ and $\mathrm{Z}$ increase in the order $\mathrm{Ni}(\mathrm{PHPO})_{2}<\mathrm{Ni}(\mathrm{CPHPO})_{2}<\mathrm{Ni}(\mathrm{MPHPO})_{2}<$ $\mathrm{Ni}(\mathrm{DMPHPO})_{2}$. The kinetic parameters show a somewhat different trend from that of thermal stability. This may be due to the fact the decisive criteria in kinetics are often quite different from those which decide thermal stability.

\section{Acknowledgements}

The author thanks Dr.R.Seshadri Naidu, Director, Academic Staff College, S.V.University, Tirupathi and Dr.N.S.Reddi, Principal, JNV, Peddapuram for their valuable suggestions.

\section{References}

1. Wendlandt W W, Anal. Chim. Acta, 1957, 17, 428.

2. Ascenzo G D and Wendlandt W W, J. Ther. Anal., 1969, 1, 423.

3. Ascenzo G D and Wendlandt W W, Anal. Chim. Acta, 1970, 50, 79.

4. Chang F C and Wendlandt W W, Thermochim Acta, 1971, 2, 293.

5. Perry D L, Vaz C and Wendlandt W W, Thermochim Acta, 1974, 9, 76.

6. Scency C G, Hill J O and Magee R J Thermochim Acta, 197511301

7. Scency C G, Smith J F, Hill J O and Magee R J, J. Therm. Anal, 1976, 9, 415. 
8. Kushuaha S C,. Dinakar and Lal J B Indian J. Chem 1967582

9. Naidu R S, Ruby R, Rao E N and Mallikarjun K G, Bull. Pure and Appl. Sci., 1987, 60, 1.

10. Naidu R S, Rao E.N, Ruby and R. Mallikarjun K G, Thermochim.Acta 1988, 131, 299.

11. Naidu R S, Ruby R., Rao E N and Mallikarjun K G, J..Indian Council Chem., 1988, 3, 41.

12. Naidu R S, Ruby R, Rao E N and Mallikarjun K G, Thermochim.Acta, 1989, 140, 97.

13. Naidu R S, Rao E N, Ruby R and Mallikarjun K G, Acta Chim Acad. Sci.Hung, 1990, 127(3), 385.

14. Mallikarjun K G and Seshadri Naidu R S Thermochimca Acta 1992.

15. Freemann E S and Carroll B, J. Phys. Chem., 1958, 62, 394.

16. Coats A W and Redfern J P, Nature, 1964, 20, 68.

17. Horowitz H H and Metzger G, Anal. Chem., 1963, 35, 1464.

18. Mistra S S and Dinakar, J. Indian Chem. Soc., 1972, 49, 6.

19. Chacko J and Parameswaran G, J. Them. Anal, 1984, 29, 3.

20. Zsako J, Varhelyi and C S, Kekedy E, J.Inorg. Nucl.Chem,. 1966, 28, 2637.

21. Khadikar P V, Ali S M and Heda B, ThermoChim.Acta, 1984, 82, 253.

22. Sawhney S S and Bansal A K, Thermochim. Acta, 1983, 66, 347. 


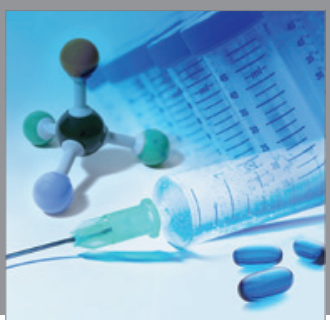

International Journal of

Medicinal Chemistry

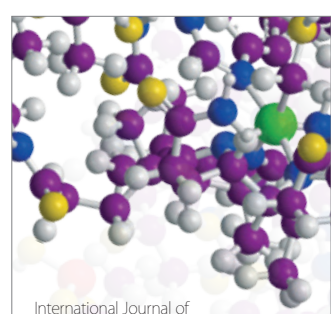

Carbohydrate Chemistry

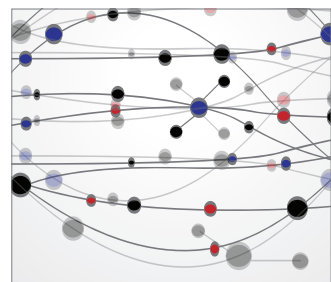

The Scientific World Journal
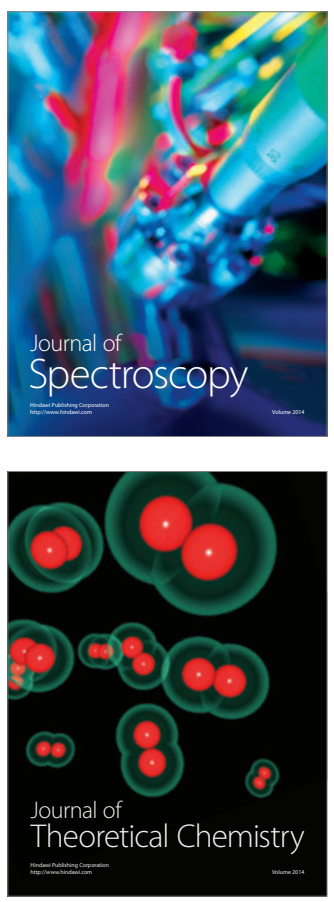
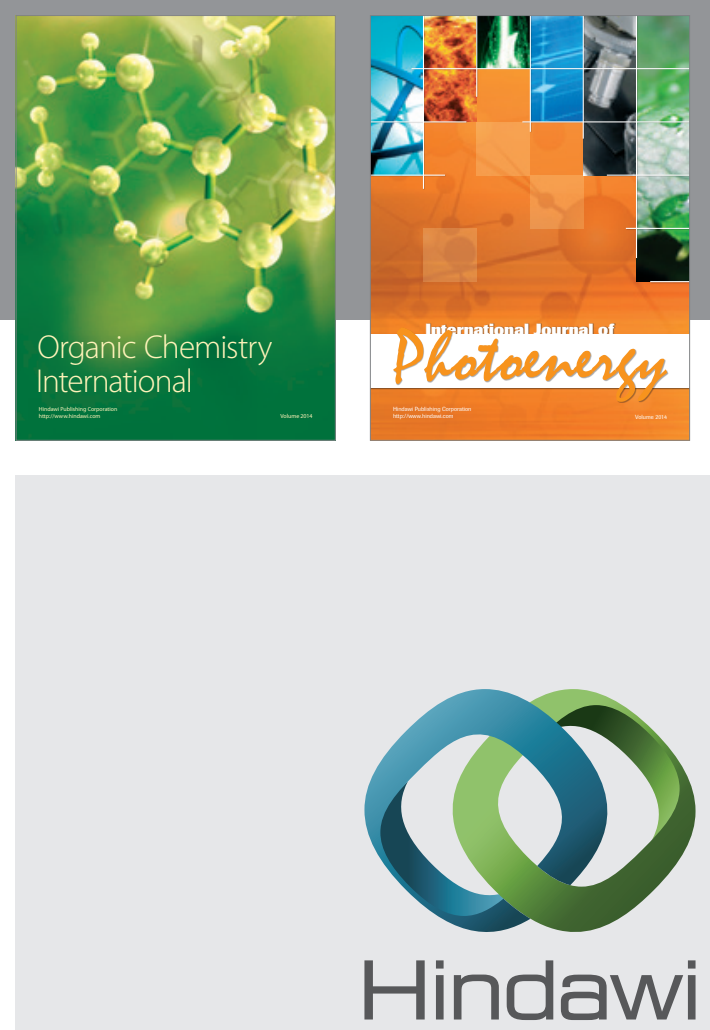

Submit your manuscripts at

http://www.hindawi.com
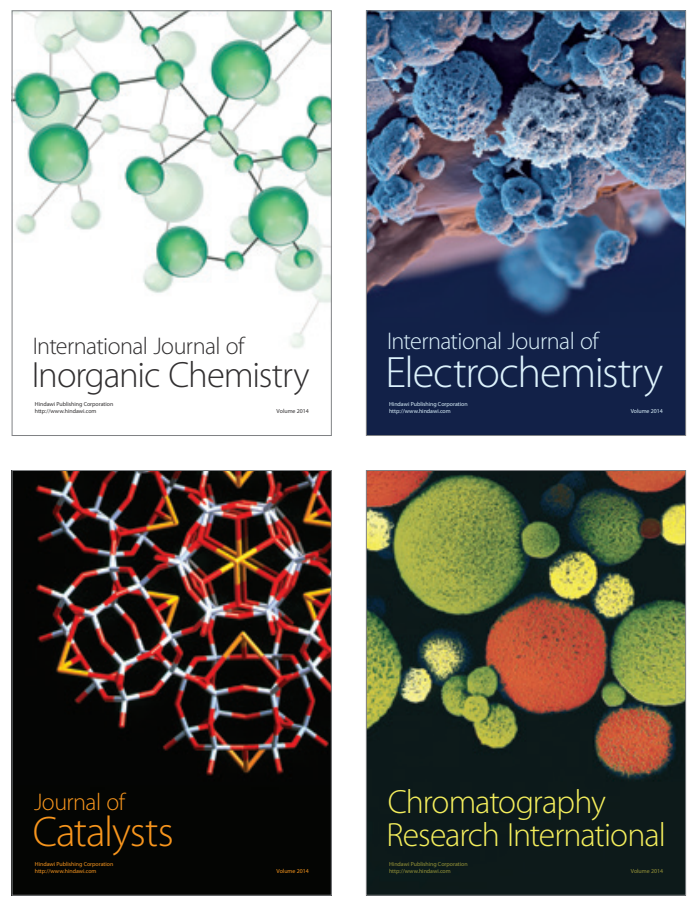
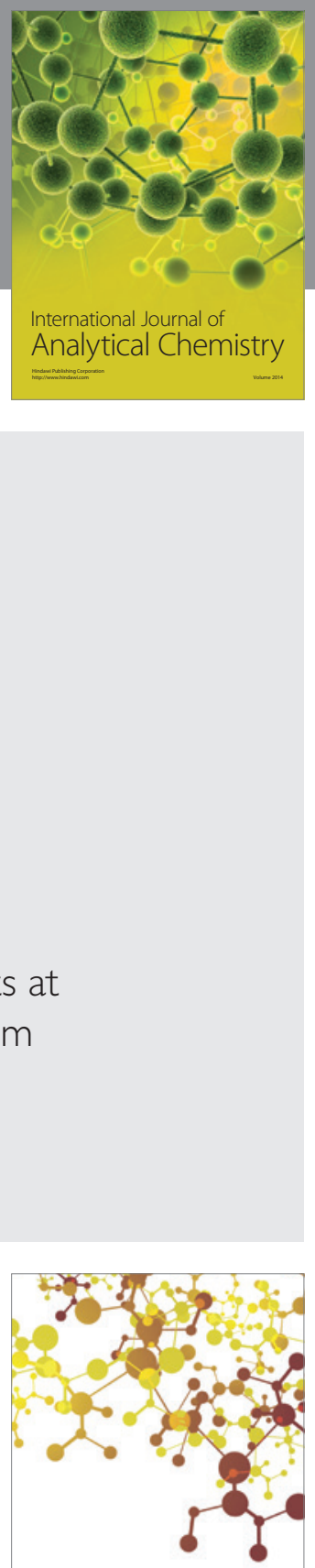

Journal of

Applied Chemistry
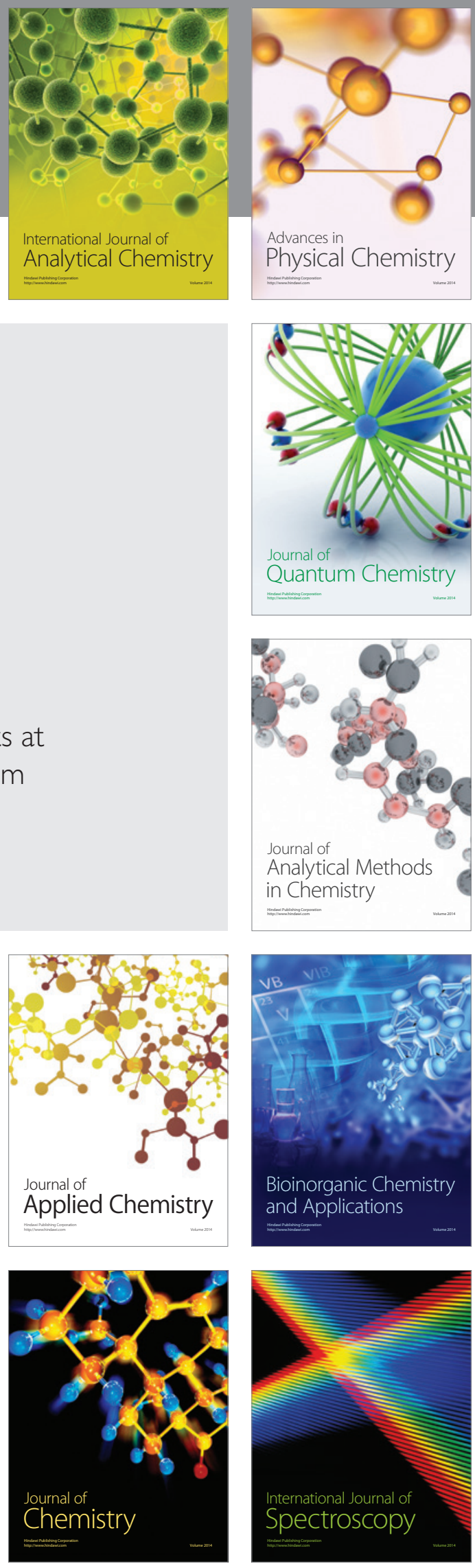